\title{
Historical Notes on Psychology in Brazil: The Creation, Growth and Sustenance of Postgraduate Education
}

\author{
Notas Históricas sobre a Psicologia no Brasil: Criação, Crescimento e \\ Consolidação da Pós-graduação
}

\author{
William B. Gomes*a \& Chris Fradkin ${ }^{\mathrm{b}}$ \\ ${ }^{a}$ Universidade Federal do Rio Grande do Sul, Porto Alegre, RS, Brazil, ${ }^{b}$ Centro Universitário La Salle, Canoas, RS, \\ Brazil
}

\begin{abstract}
This article presents a brief overview of the history of psychology in Brazil. It highlights how the Brazilian Association of Research and Postgraduate Studies in Psychology (ANPEPP - Associação Nacional de Pesquisa e Pós-graduação em Psicologia) has fulfilled its mission of fostering discussion on scientific policy and stimulating interchange among researchers. First, it provides a retrospect of ANPEPP meetings, considering both: 1) the thematic working groups, which have served to bring together researchers, and to inspire the emergence of thematic associations and journals; 2 ) the discussion forums, which have contributed in the critical review of scientific policy, and the mission of postgraduate studies. Second, it focuses on the history of psychology in Brazil, from colonial times to the recent national commitment to postgraduate studies. The paper argues that the plans and strategies led by national funding agencies have been successful and that their results are evidenced by the role played by Brazil in the international arena, both in scientific production and the training of its researchers. By sustaining current policies, it seems certain that, even with the oscillations in the national economy, postgraduate education will grow steadily in its advance of the psychological sciences; and will be working towards a better quality of life, social justice and ecological sustainability.
\end{abstract}

Keywords: ANPEPP, CAPES, CNPq, history of psychology, postgraduate studies, Brazil.

\begin{abstract}
Resumo
O artigo apresenta breve resenha da história da psicologia no Brasil para ressaltar como a ANPEPP - Associação Nacional de Pesquisa e Pós-graduação em Psicologia tem respondido à missão de fomentar o debate em políticas científicas e estimular o intercâmbio entre pesquisadores. $\mathrm{O}$ artigo traz um retrospecto das reuniões da ANPEPP, destacando ambos: 1) os grupos de trabalho temáticos, os quais têm servido para agregar pesquisadores e inspirar o surgimento de associações temáticas e revistas; 2) os fóruns de discussão, os quais têm contribuído para a revisão crítica de políticas científicas e da missão da pós-graduação. A seguir, a atenção se volta à história da psicologia no Brasil, dos tempos coloniais aos recentes planos nacionais para a pós-graduação. A ideia é ressaltar a inserção da pós-graduação na cultura universitária brasileira. Argumenta que os planos e estratégias oriundas das agências de fomento têm obtido bons resultados, evidenciados pelo papel que o Brasil ocupa no cenário internacional, em produção científica e formação de pesquisadores. Mantendo essas políticas, é certo que apesar de oscilações na economia nacional, a pós-graduação está caminhando em passos firmes para o avanço da ciência psicológica e trabalhando em favor da qualidade de vida, da justiça social e da sustentabilidade.

Palavras-chave: ANPEPP, CAPES, CNPq, história da psicologia, pós-graduação, Brasil.
\end{abstract}

This Supplement of PRC/Psychology is dedicated to the discussion forums of the Brazilian Association of Research and Postgraduate Studies in Psychology

\footnotetext{
Address for Correspondence: Programa de Pós-graduação em Psicologia, Rua Ramiro Barcelos 2600, 90035-003 Porto Alegre-RS, Brazil, Email: gomesw@ ufrgs.br. Chris Fradkin's contribution was funded by a pós-doc through Coordenação de Aperfeiçoamento de Pessoal de Nivel Superior (CAPES), Ministério da Educação, Brasil. William B. Gomes is a past president of ANPEPP. His contribution was funded by $\mathrm{CNPq} / \mathrm{CAPES}$. He is a CNPq/Produtivity $1 \mathrm{~A}$.
}

(Associação Nacional de Pesquisa e Pós-graduação em Psicologia), referred to as ANPEPP. The articles published in this Supplement came from two meetings held in 2014. The first was the fifteenth Symposium on Scientific Research and Exchange that took place in Bento Gonçalves, Rio Grande do Sul state, May 6-9; the second was the III Seminars New Horizons of Postgraduate Studies in Psychology held in Campinas, São Paulo 
state, September 22-24. ANPEPP symposia aimed to strengthen the scientific exchange among professors and postgraduate programs, to encourage the creation of thematic research networks, and to promote debates about scientific policies and knowledge advancement. By its turn, ANPEPP seminars promote a dialogue on current issues in research, teaching, scientific policy, and the new strategies and demands upon postgraduate education. Indeed, it is a dialogue between ANPEPP (postgraduate programs) and CAPES - Coordination for the Improvement of Higher Education (Coordenação de Aperfeiçoamento de Pessoal de Nivel Superior), a government agency linked to the Brazilian Ministry of Education in charge of promoting high standards for postgraduate courses. CAPES not only provides the guidelines but also monitors the performance of postgraduate programs through periodic detailed evaluations, which were initially every two, then three, and now every four years. Thus, an important issue at the seminars is the evaluation form and the values assigned to rank the programs. CAPES is represented in the seminars by its psychology coordination area.

This article provides information about the history of higher education in Brazil, with regard to the research and teaching of psychology. It traces the shifting of roles, from scientific societies to the creation and development of national agencies for structuring research enterprises. In addition, it provides a brief overview of the scientific progress of psychology in Brazil to illustrate how ANPEPP has fulfilled its mission of fostering discussion on scientific policy and stimulating interchange among researchers in psychology. The present exposition will follow an inverse order. First, we will present a chronicle of ANPEPP symposia and seminars. Then we will bring a brief note about the history of higher education in Brazil, with particular attention to the advancement of psychology from colonial times until the recent CAPES' National Plans for Postgraduate Studies.

\section{Part I:}

\section{ANPEPP symposia and seminars}

Scientific associations emerge responding to demands from specific fields of knowledge. Some of them are short-lived; others establish themselves over time and become a bastion in a scientific field or subfield. The goal of these associations may be summarized in four points: 1) discussion of scientific topics; 2) coordination and monitoring of scientific studies; 3 ) promotion and dissemination of science through meetings, publications and awards; 4) defense of the association's particular scientific field and of its membership. In Brazil, the general scientific community is represented by the Brazilian Society for the Advancement of Science (Sociedade Brasileira para o Progresso da Ciência-SBPC), founded in 1948, which articulates, promotes and defends scientific and technological development. Thus, SBPC played an important role in the creation of the two Brazilian main funding agencies: CAPES and CNPq- Brazilian National Council for Scientific and Technological Development (Conselho Nacional de Desenvolvimento Científico e Tecnológico), in 1951.

In the field of psychology, other associations also contributed by disseminating and consolidating the new science-for psychology was new then, in Brazil—with professional training and monitoring. Some of these pioneering associations remain active today, such as the Psychological Society of São Paulo state (founded in 1945), and the Psychological Society of Rio Grande do Sul state (founded in 1959). On the national stage, there was the Brazilian Psychological Association, which was established in 1954 in Rio de Janeiro but succumbed in the 1990s, but not before ensuring that the emerging Brazilian Psychological Society would be the depository of its archives. The Brazilian Psychological Society, which was actually the successor to the Psychological Society of Ribeirão Preto City/São Paulo state, thrived in the 1980s and 1990s with its well-articulated and large annual meetings. During the 1990s, thematic associations flourished, with the Brazilian Association of Social Psychology (Associação Brasileira de Psicologia Social - ABRAPSO) the most striking example. ABRAPSO was founded in July, 1980 and has turned its biannual congress into one of the most well-attended events in Brazilian psychology.

By its turn, ANPEPP has a peculiar history. It was introduced by CAPES to help articulate postgraduate programs in psychology. CAPES' main interest was to give support and structure to the social sciences, considering that the physical and biological sciences were already being consolidated throughout the country (Guedes, 2002; Schliemann, 2015). Such formats, known as ANPs (associações nacionais de pós-graduação - national postgraduate associations), had already shown positive results since the creation of ANPEC (National Association of Postgraduate Centers in Economics) in 1972; ANPAD in Business Administration in 1976; ANPED in Education in 1978; ANPOF in Philosophy in 1983; and ANPPOM in Music in 1988. Our ANPEPP was launched at the $35^{\text {th }}$ Annual Meeting of the Brazilian Society for the Advancement of Science (Sociedade Brasileira para o Progresso da Ciência - SBPC), July, 1983, in Belém, Pará state.

ANPEPP Symposia were initiated years later by suggestion of the CNPq Advisory Committee for Psychology. The committee was composed at that time (early 1980s) of professors Angela Biaggio, Terezinha Carraher and Thimoty Mulholland. The committee understood that the time had come for researchers in psychology to familiarize themselves with the work of their peers (Schliemann \& Falcão, 1988). The board of the initiating ANPEPP accepted the challenge and in March, 1988, promoted the first Symposium for Research and Scientific Exchange in 
the city of Caruaru-PE.

All postgraduate programs were invited to send up to three professors for the first ANPEPP Symposium. At that time, there were only 15 master's and 6 doctoral programs in Brazil. Of these programs, most of them sent their representatives, which resulted in 43 exchanges at which researchers presented and debated their lines of research and their findings. The Symposium expected to and managed to ascertain the level of research conducted in postgraduate programs, regarding clarity and development of research lines, materials and methods, and integration between topics and researchers. According to the organizers' postsymposium evaluation (Camino \& Schliemann, 1988, p. 275): "there was more research in Psychology in Brazil than expected," and "the quality of the studies was heterogeneous, with high-quality ones being presented alongside studies of little or no theoretical or even practical relevance, plus studies which indicated the author's lack of knowledge regarding not only basic methods and techniques of research, but also of their area of expertise." Most importantly, the Symposium went on; its design was being fine-tuned and participants increased.

The second Symposium in Gramado, Rio Grande do Sul state, in 1989, was organized in a format of working groups (WGs). Ten previously articulated groups registered for the conference. The idea of working groups actually originated in the final session of the Caruaru meeting, with WGs envisioned as a context in which researchers working in a common field could present their findings and results, for discussion and debate among its members. It was hoped that these groups would produce work in collaboration. At the same symposium, it was suggested that the most distinguished professors be invited to speak about their work; to present the "state of the art" in different subfields (Camino \& Schliemann, 1988). From these two recommendations, the one which flourished was the concept of WGs, which resulted in 20 WGs for the fifth Symposium in 1994 in Caxambu, Minas Gerais state; 41 WGs for the tenth Symposium in 2004 at Aracruz, Espírito Santo state; and 68 WGs for the fifteenth Symposium in Bento Gonçalves, Rio Grande do Sul, state. ${ }^{1}$

The most impressive outcome was that the WGs became vectors of attraction for the Symposium, assembling distinct profiles of Brazilian researchers in psychology. According to the proceedings of the fifteenth Symposium, the WGs included among their members almost all professors and coordinators of postgraduate programs, 14 presidents of national and international scientific associations, a vice president of SBPC, a university rector (president) and vice-rectors. Each event has reasserted the ANPEPP Symposium as the most

\footnotetext{
See ANPEPP site: http://www.anpepp.org.br/conteudo/view?ID_CONTEU-
} $\mathrm{DO}=33$ outstanding meeting in Brazilian psychological science. ${ }^{2}$

Certainly the creators of the Symposia in WGs format never imagined that it would persist throughout the years, and that this format would bravely resist the easy access for scientific exchange provided through electronic media. Currently, a researcher who has never joined an ANPEPP/WG, or is momentarily not affiliated with any WG may argue: 1) that her/his refined focus of interest has not yet been contemplated; 2) that her/his WG failed, for some reason, to articulate and submit a proposal; and 3) that a political dispute (over leadership or thematic content) dissolved or divided her/his WG. At the same time, the enthusiasm for the creation of new WGs signals the format's continuity, despite its inherent logistic implications, considering the challenges of staging so many simultaneous meetings (around 70).

Even so, since the second Symposium a smaller part of the program was dedicated to roundtables in order to discuss the state of the art in psychology subfields. In the fourth Symposium at Brasília in 1992, the members discussed the relationship between postgraduate studies and undergraduate professional training, and started to think about organizing and indexing Brazilian psychological journals ${ }^{3}$. In the following Symposium at Caxambu, Minas Gerais state in 1994, the focus at the roundtable changed from psychological subfields to scientific policies and the social relevance of our research. These issues remained dominant throughout the next events. Ten years later, at the tenth Symposium in Aracruz, Espirito Santo state, the studies and debates on research ethics, scientific policy, publications and productivity, as well as discourse on the relationship between undergraduate professional training and postgraduate research studies, along with other timely topics, took on another name. They were referred to as ANPEPP Forums. However, symposia meetings did not seem to have enough time for those discussions. Therefore, in 2008 the Seminar New Horizons of Postgraduate Studies in Psychology was created to increase time for debates and referrals in ethics, scientific policies, postgraduate goals, and research internationalization.

The first Seminar New Horizons was held November 9-12, 2008, at Bento Gonçalves, a choice place for meetings because of the mild climate of the mountains. The following agenda was proposed for postgraduate education: 1) profile, evaluation and intellectual goals; 2) gaps, goals and conditions for expansion; 3) internationalization profile and qualification goals; and 4) new challenges. The resulting papers were published in PRC/Psychology, Vol 23, Supplement 1, 2010. These papers set forth thoughtful and detailed analysis on the current state of graduate studies, and included suggestions for CAPES policy and its

\footnotetext{
See ANPEPP site: http://www.anpepp.org.br/arquivo/download?ID_ARQUIVO $=438$

The Federal Council of Psychology took over the coordination of this project, creating an index called Virtual Library of Psychology in Latin America - BVS Psychology.
} 
monitoring of research activities, professors' and students' performance, and master's and doctoral program proposals.

The seminar focal points were productivity, internationalization and regional asymmetry in postgraduate education. For productivity, it was suggested that not only articles, chapters and books should be considered as relevant for CAPES' evaluation, but also new formats such as audiovisuals and software. Variations on work deadlines was another aspect discussed in productivity, since realistic time requirements vary across subfields. For goals it was suggested that: 1) every Brazilian state should have a postgraduate program in psychology; 2) institutions with a consolidated master's program should plan to add a doctoral program; 3 ) the number of doctoral graduates should be increased by $10 \%$ per year; 4) technical terms that were used to name research lines or concentration areas should be clarified, since there is not consensus on them; 5) leadership training for subfields (e.g., social politics, health psychology) should be incentivized; and 6) the application of postgraduate advanced studies to professional training should be seriously considered. With regard to professional training, CAPES is now encouraging postgraduate programs to offer not only an academic master's degree but also a professional master's degree. The goal is to place postgraduate training personnel not only in higher-education institutions; but also in hospitals, public service, and the private sector.

Internationalization has become an impassioned topic in Brazilian science, especially in the social sciences. In Brazil, programs in the natural sciences have sophisticated international exchange and collaboration, which has resulted in English-language publication for some time. This is not the case in the social sciences. Although Brazil's social scientists have a comfortable relationship with scientists from other countries, and receive scholars in Brazil, for the most part they do not publish in English. In defense, these social scientists argue that their studies are culturally specific, and of little interest to the outside world. While this argument may be valid for some subfields of the social sciences, for psychology it brings a problem. As English is the current lingua franca, or language of science, for Brazilian psychologists to publish and reach the global market they must publish in English-language journals (Meneghini \& Packer, 2007).

In the first New Horizons Seminar, the challenges identified for postgraduate studies were (Tourinho \& Bastos, 2010, p. 35):

a) The expansion of the geographical and thematic scope in order to overcome regional asymmetries and thematic gaps in psychological research; b) the improvement of the evaluation system in order to comprise diverse strategies in the instruction of new researchers and knowledge production in diverse subareas of psychology; c) the necessity of a link among different areas of postgraduate programs, since the basis for knowledge production in this field may necessitate development of intervention technologies; and (d) the elaboration of policies which may qualify the system, improving the research networks, providing international exchange for the groups, promoting scientific publications, and extensive methodological learning.

Discussions and propositions for postgraduate studies in psychology continued at the second New Horizons Seminar, held in Brasilia, December 5-6, 2011. Concerns were focused on: 1) how to incorporate and evaluate technological innovations; 2) how to increase the quality of published articles; 3 ) how to effectively associate services with research activities; 4) how to encourage supportive collaboration, in which consolidated programs could help new ones develop; 5) how to guide programs in the training of university teachers; and 6) how to increase the offerings of professional master's programs.

Unfortunately Psicologia: Reflexão e Crítica did not have a publication dedicated to the second seminar, but the reports presented in the final sessions by the respective committees were very enlightening. The main recommendations are outlined as follows: 1) transference of technology and innovation must be shaped carefully by specific agendae, linked to research projects with clearly defined social impact; 2) upgrading of scientific publication should involve proper training of students on scientific writing, professionalization of journals, and better working conditions for editors whose work is undervalued by CAPES; 3) transference of knowledge to society via technology and services is a desired initiative and should be articulated within research lines according to regional and national demands; 4) collaboration between programs should be encouraged through funding agencies, which should be more flexible in providing grants for collaboration between programs with shared interests; and 5) without neglecting research training, postgraduate programs should encourage educational training, development of teaching manuals, and the reinstatement of approaches from past successful programs. Points regarding Professional Master's programs addressed weaknesses in training of psychologists (undergraduate level in Brazil), as well as lack of evaluation for the specialization training (postgraduate lato sensu) offered by higher education institutions and independent educational centers. In fact, many academic master's programs present a professional master's profile, but their characteristics and scope are unclear, and they still function as academic programs.

In the second seminar, tension between different types of programs, products and scholarly work and requirements of CAPES' evaluations ran through the debates. The concern seemed to be with what is done, what should be done, how activities and products are recorded in the CAPES' evaluation form, and how this form is scored. On the one hand, the strict supervision of CAPES forged the development of postgraduate studies; on the other, it 
created a tremendous stress on how to meet the required criteria and how to attend to the intellectual and social demands of all the programs, faculty, students, and society.

This brief review of the past two New Horizons Seminars enables us to understand the progress made so far. The articles in this supplement update us to issues that have been regularly discussed, and bring new and vital issues to the forefront: Brazilian scientific policies (Bastos, Tomanari, Trindade, \& Andery, 2015; Guzzo, Linhares, Teodoro, \& Koller, 2015), ethical standards for psychological research (Leitão, Falcão, \& Maluf, 2015), internationalization (Hutz, Yamamoto, \& Lo Bianco, 2015; Menandro, Linhares, Bastos, \& Dell'Aglio, 2015), Latin American international publication (Fradkin, 2015; Gamba, Packer, \& Meneghini, 2015; Lopez-Lopez, Anegón, AcevedoTriana, \& Garcia, 2015; VandenBos \& Winkler, 2015), and transference of journal management to international publishers (Gracia, 2015).

CAPES' point of view was presented by the coordinators of the psychology area (Bastos et al., 2015). Their report suggested that postgraduate studies in psychology are growing at a moderate rate, comprising the second largest area in the human sciences. The number of programs has increased and expanded in geographical distribution, expanding mainly in the northern and central-western regions. They also indicated that our doctoral and master's graduates are moving on to both higher education and the professional market. However, they point out some important aspects that need improvement: 1) training teachers and professionals for careers in basic education, an important Brazilian necessity; 2) differentiating curricula in academic versus professional programs; and 3) expanding our presence in the international market through transferring editing responsibilities of our psychology journals to professional Englishlanguage publishers. They concluded by stating that our programs' growth and success depends on openness to critiques and suggestions and the vision of our programs as a whole.

ANPEPP's point of view was presented by its committee on scientific policies (Guzzo et al., 2015). They recognized that CAPES' policies have an enormous impact on programs' maintenance, scientific production, and student training, through their financial commitment to infrastructure, scholarship, and technological innovations. Also, this dependence on federal grants requires strong adherence of our programs, faculty and students to fulfill their obligations to the regulatory agencies. In turn, programs should have updated curricula and they should seriously consider engaging in internationalization. And consequently, agencies should be mindful of monitoring program activities and the use of public funds.

ANPEPP's Ethics Commission and other human science associations are working on an agreement between the National Research Ethics Commission (Comissão Nacional de Ética em Pesquisa - CONPEP) and CNPq to make a distinction between bioethics and ethics for the social sciences. Leitão and colleagues (2015) traced the origins of bioethics and argued that this norm is not only inadequate for research in the humanities, but also may create serious ethical dilemmas for participants and researchers. The good news is that $\mathrm{CNPq}$ was sensitive to the arguments and considered dedicating a department to the social sciences, where these more specific standards would be contemplated.

Internationalization could be considered the main issue of the two ANPEPP meetings in 2014, and obviously it is well represented in this PRC/Supplement. Brazilian scientific policies have emphasized the need both: to disseminate our sciences and to promote interchange with countries round the world. This means: sending students and faculty abroad and receiving foreign students and faculty at home; facilitating collaboration between Brazilians and researchers from other countries; having an active presence at international conferences, and, most of all, publishing in English. For the first time, we have the opportunity to appreciate the point of view of Brazilian postgraduate faculty (Hutz et al., 2015; Menandro et al., 2015) and foreign researchers: from US (VandenBos \& Winkler, 2015), Europe (Gracia, 2015), and Latin America (Lopez-Lopez et al., 2015).

Brazilian views contrast international actions with international publication, demonstrating that actions are overwhelmingly present in the programs, while publication, strongly valued in CAPES' evaluations, is still weak in many programs and subfields (Hutz et al., 2015). In fact, international publication seems more associated with certain subfields than others. This reality is clearly indicated by VandenBos and Winkler (2015) and by Gamba, Packer, and Meneghini (2015). The data they collected give the idea that experimental psychology, pharmacology, abnormal psychology, and neuroscience represent the bulk of Brazilian publication, but this is not true. Their data only reflect the number of publications in English. In psychology, the major subfields in Brazil are clinical psychology, psychoanalysis, and social psychology. These are areas, for the most part, researchers prefer to disseminate their work in Portuguese.

In fact, there is great debate as to whether the use of English is really desired, considering the vast professional field of psychology which requires updates in Brazil's native language, Portuguese. In any case, the use of English in the humanities is growing in Brazil, as well as in Spanish and French speaking countries. Gracia's (2015) article is illustrative in that sense because it describes the journey from Spanish to English of a journal that he edits in Spain, Psychosocial Intervention. Interestingly, the journal is not nested in a subfield that traditionally publishes in English, which may be further indication that lingua franca publication is necessary for 
scientific communication. Further evidence followed ANPEPP's fifteenth Symposium with two journals forming partnerships with lingua franca publishers: PRC/ Psychology (Psicologia; Reflexão e Crítica) in partnership with Springer, and Psychology and Neuroscience with the American Psychological Association.

\section{Part II:}

\section{Psychology postgraduate studies in Brazilian higher education}

We will move now from the history of ANPEPP meetings to the history of psychology in Brazil. The idea is to provide a context so that non-Brazilians can understand the way our university programs came about; and how our journey to make science thus evolved. This is organized in: 1) attempts to introduce higher education, 2) first universities, 3) organization of psychology as science and practice, 4) training in psychology and postgraduate studies, and 5) CAPES' national plans for postgraduate studies. We conclude that Brazil was slow to engage in higher education policies, being one of the last countries in Latin America to create a university (with the first founded in 1920). Moving forward to the 1960s, we see government reformulating its policies for higher education, recognizing postgraduate studies as a higher education level, and fostering a well-articulated plan for scientific and technological development. Brazil is now noted for its successful scientific policies, and a well-articulated program for training researchers.

\section{Higher education}

Since colonial times, there were many attempts to establish universities in Brazil. These include efforts (Cunha, 2007) of: 1) the Dutch invaders in Recife, Pernambuco state in 1637; 2) the City Council in Salvador Bahia state in 1663; and 3) the Minas Conspiracy, an unsuccessful Brazilian independence movement, in São João Del Rey, Minas state in 1786. However, not until the nineteenth century would higher education institutions be established in Brazil; beginning with the military engineering schools, founded when the Portuguese Kingdom was transferred from Lisbon to Rio de Janeiro, to escape the French invasion in the Napoleonic war.

In the early nineteenth century two models of higher education inspired universities around the world: 1) the highly centralized French Napoleonic concept; and 2) the autonomous, research-oriented Germanic concept. Brazil followed the French grands écoles premises of the Napoleonic concept, with higher education institutions being guided and monitored by the central government (Lucchesi, 2011; Oliven, 2014). The main function of this model was to meet the nation's need for specialized professional services. In contrast, the Germanic university concept would highlight academic autonomy with a focus on research (Hearnshaw, 1987). In the beginning, therefore, higher education in Brazil was characterized by schools to train professionals as physicians, dentists, lawyers, and engineers. Training in philosophy was obtained by religious students through theology courses, and training in pedagogy for literacy and elementary education was offered through the teaching colleges (Hutz, Gauer, \& Gomes, 2012). The first professional law schools were created in 1827 at Pernambuco and São Paulo, and the first professional medical schools were created in 1832 at Salvador and Rio de Janeiro.

The first formal Brazilian university was organized in 1920 at Rio de Janeiro, federal capital at that time (Favero, 2010). Previously, however, the demand for higher education had been growing and several Brazilian states had created their own free universities: Amazonas state in 1909, São Paulo state in 1911, and Paraná state in 1912 (Cunha, 2007). Interestingly, the first Brazilian Republicans, driven by French positivism, opposed the creation of Brazil's first universities, because these universities represented to them the obscure spirit of medieval institutions, with their isolation from scientific and technological development (Costa, 1967).

The concept of higher education in Brazil began to change in 1934 with the founding of the University of São Paulo USP. This institution was masterminded by wealthy families to provide high-quality education for their children. Qualified faculty were imported from France (USP, 1994), among them historian Fernand Braudel (1902-1985), philosopher Jean Maugüé (1904-1990), and anthropologist Claude LéviStrauss (1908-2009). USP was the first Brazilian university devoted to scientific investigation and research training. In the field of psychology (Campos, 2001), at the same university, scientific research was bolstered by American social psychologist Otto Klineberg (1899-1992) in the 1940s; and American behaviorist Fred Simmons Keller (18991996) in the 1960s. Even so, the Napoleonic concept still dominated, with Brazil's national higher education system strictly regulated and monitored by the federal government.

Historically, the great supporter of higher education in Brazil was Anísio Teixeira (1900-1971), first president of CAPES in the years 1952/53 (Mendonça, 2004). According to Teixeira (1989) the contemporary university should be: 1) humanistic, offering a general, philosophical, and basic training, like a medieval university; 2) modern, focusing on research and production of knowledge, like the Humboldt University of Berlin; 3) social, in examining societal problems, like the Newman University (training the mind rather than diffusing useful knowledge); and 4) a multiversity, linking industry and national development.

However, the development of higher education around the country was slow, with a progressive organization of public universities occurring in the most populous states in the 1940s and 1950s. These universities were gradually federalized in the 1950s and early 1960s. The spectacular growth of higher education in Brazil started in the 1970s, intensifying in the 1990s, provided mainly by religious 
organizations, and the private sector. Nevertheless, despite many advances, we are still far from the ideal of Anísio Teixeira. The postgraduate studies are the domain we have yet to put in place, to fulfill Teixeira's proposals.

\section{Psychology as a subject in Brazil}

Psychology has a long history in Brazil (Massimi, 1990). Notions of philosophical psychology were introduced in Brazil by Catholic priests during the colonial times. In general, the priests belonged to the Jesuit and Franciscan congregations, with their theories based on the ideas of Augustine of Hippo (354-430) and Thomas Aquinas (1225-1274). These priests, however, were smitten by the interpersonal relations and child care of the indigenous and local Amerindians. The Jesuits were particularly impressed with the loving relationship between parents and their infants, observed especially among mothers breastfeeding their young children. Amerindian parents related to their children without any aggression, and used toys and games to prepare them for adult life. Certainly, these priests were inspired by the Amerindians when composing their child-rearing manuals, such as The Art of Well Training the Children When They Are Very Young, written by the Jesuit Alexandre Gusmão (16291724) and first published in 1685 (Hutz, Gauer, \& Gomes, 2012; Massimi, 1990).

The new psychology began to arrive in the middle of the nineteenth century with physicians and lawyers who had studied in Europe, and with elementary school teachers from the US, sent by Presbyterians and Methodists (Massimi, 1990). We Brazilians used to say that psychology arrived in Brazil in the hands of theologians (general theories), physicians (experimental essays, psychopathology, projective techniques), lawyers (social behavior, delinquency), educators (counseling, guidance, intelligence measurements), and engineers (vocational guidance). In 1854, França (1809-1857), a professor at the Medical School in Salvador, Bahia state, and a graduate of the University of Paris in 1834, wrote a treatise on Psychological Investigations. He attempted to reconcile two apparently incompatible French doctrines: the empirical sensationalism of Étienne Bonnot de Condillac (1714-1780) and the mystical theosophism of Maine de Biran (1766-1824). Indeed, reports on monographic essays submitted at the end of the medical programs show they were attentive to the scientific progress in the field of psychology that occurred in Germany and France. The themes included: duration of elementary psychic acts, psychophysiology of perception and representation, and psychoclinical study of aphasia (Gomes, 2003; Massimi, 1990; Pessotti, 1988). Interestingly, the two medical schools (Rio de Janeiro and Salvador) had different approaches to psychology. The school at Rio de Janeiro was more concerned with neuropsychiatry, psychophysiology, and neurology. In contrast, the school at Bahia was more focused on the study of criminology, forensic psychiatry, mental hygiene, social psychology, and pedagogy. With government support, two psychiatrists were sent to France for laboratory internships in psychology: Manoel Bomfim (1868-1932) with Alfred Binet (1857-1946), and Maurício de Medeiros (1885-1966) with George Dumas (1866-1946). Post-internship, both psychiatrists returned to Rio de Janeiro where they set up laboratories for educational and psychiatric applications. Soon after, two European psychologists came to Brazil and also set up laboratories. The Italian psychologist, Ugo Pizzoli (1863-1934), set up a laboratory at a teaching college in the city of São Paulo (Centofanti \& Tomasini, 2014), and the Polish psychologist, Waclaw Radecki (1887-1953), in a psychiatric hospital in Rio de Janeiro (Centofanti, 1982).

Likewise, interest in psychological applications rose sharply in the first half of the twentieth century. Journalists began to suggest psychometrics as a solution to injustice on assessments of students in medical schools; psychiatrists began to study, discuss and apply psychoanalytic theories; and schools began to organize psycho-pedagogical services for children and mental hygiene assistance for families. Psychological instruments (e.g., IQ tests) were translated into Portuguese and adapted to the Brazilian population; and psychiatrists started using the Rorschach inkblot test for psycho-diagnosis (Hutz, Gauer, \& Gomes, 2012).

Thus, the responsibilities for psychological applications were divided among educators and psychiatrists, the reason being: at this time there were no training programs for the psychological sciences and none for clinical practice. This situation began to change with the advent of the bachelor's degree in philosophy. This degree was offered in Brazil by new higher education institutions that proliferated in the 1940s. In these philosophy programs, the area of psychology came to occupy much of the curriculum, which also offered degrees that led to teaching licensure, where educational psychology was studied. Some of these programs taught psychological testing in the classroom, and required internships in psychiatric hospitals. From these programs came the first Brazilian psychologists in the 1950s. In the same decade there was considerable debate about recognizing this new profession; plus debate on how to train these new professionals. The recognition came on August 27, 1962, with the title of psychologist bestowed on students who had completed the degree requirements in psychology. Thus psychologist reached the status of a professional graduate degree; with diploma holders in this field now eligible for a license to proceed into professional practice (Brasil, 1962).

\section{Professional psychologist licensing: undergraduate training programs}

Professional training in psychology started in the $1950 \mathrm{~s}$ as a kind of postgraduate specialization course offered by private institutions as autonomous initiatives, without governmental supervision. With the recognition of psychology as a profession in 1962, higher 
education institutions were now authorized to offer five-year undergraduate programs to train and educate the professional psychologist. These programs were characterized by a broad curriculum, which included research methods, statistics, diagnosis, and practicum as specialized training in clinical, educational, and organizational practices. Once the program curriculum was successfully completed, the students received the psychology degree. They were then eligible for the professional license from the Ministry of Education. In the early 1970s, however, the federal government created the federal council and regional councils of psychology, which overtook the functions of licensing and supervising professional practice.

The law that recognized psychology as a profession in Brazil ${ }^{4}$ mandated that the degree of psychology be offered in a five-year program. The first four years granted a Bachelor's Degree if the curricular emphasis was on research or a Licensure's Degree, if the curricular emphasis was on teaching. The fifth year was dedicated to professional practice, including a supervised internship of 500 hours in a psychological service. The service had to be accredited by the higher education institution that offered the undergraduate program of psychology. The basic subjects for the Bachelor's Degree were: physiology, statistics, general and experimental psychology, developmental psychology, personality psychology, social psychology, and general psychopathology. For the 'psychologist' degree, the subjects of psychological evaluation and counseling, and professional ethics were added, and three more subjects among the following: psychology for special educational, group dynamics and human relations, therapeutic pedagogy, school psychology and learning problems, personnel selection and psychological guidance, and industrial and work psychology. The government decree that recognized the profession also defined the psychologist's functions: 1) using methods and psychological techniques geared towards: psychological diagnosis, personnel selection and vocational guidance, psycho-pedagogical orientation, and treatment for adjustment problems; 2) assuming responsibility for psychological services offered by public and private institutions; 3 ) teaching psychology at the various educational levels, according to the current legislation; 4) supervising professionals and students on theoretical and practical work in psychology; 5) advising public and private institutions on psychological matters; 6) issuing legal psychological reports when necessary and pertinent.

During this period, the curriculum for a psychology career was becoming flexible and its contents were being shaped by the dominant theories of the time (psychoanalysis,

Brasil: Ministério da Educação (1962). Lei 4.119, de 27 de agosto que dispõe sobre os cursos de formação em psicologia e regulamenta a profissão de psicólogo. Retrieved from http:// site.cfp.org.br/wp-content/uploads/2008/08/ behaviorism, humanism, social history). From the 1960s through the first half part of the 1970s psychological evaluation occupied a large part of the curriculum. With the advances of North-American behaviorism, French psychoanalysis and Brazilian social history, psychological tests had given way to a more therapeutic and political approach. Behaviorism and humanism were never strong theories in Brazil, what with psychoanalysis and social history the dominant interest. Training in experimental psychology was weak and research barely existed. The minimum curriculum would undergo major changes at the turn of the twenty-first century, when the National Secretary of Education (Ministério da Educação) promulgated new guidelines for undergraduate courses in psychology, as we shall see later in this article.

\section{Psychology research and teaching: postgraduate studies}

Postgraduate studies emerged in this scenario of expanded training for psychologists. These programs were designed to foster research training, along with teaching strategies for undergraduate courses. Note, however, that the master's and doctoral courses do not lead to professional licensure. This is the case even if the student's master's thesis or doctoral dissertation were on psychotherapy or clinical psychology. Rather, it is the psychology undergraduate programs that enable the graduate to obtain the professional license from the governmental agencies. This is a key point between undergraduate and postgraduate education in Brazil. This distinction, however, is more organic when expressed in Spanish language. In Spanish, for example, 'pregrado' means before the degree, while 'posgrado' means after the degree. In Brazilian Portuguese, the word 'graduação' refers to undergraduate education which leads the graduate to professional licensure. In the United Kingdom, by the way, the same distinction occurs between undergraduate and postgraduate education.

The doctoral degree, however, was no stranger to higher education in Brazil (Schwartzman, 1991). The first medical and law schools in the early 1830s granted the title of doctor through the submission of a monograph, which was examined by a faculty committee. However, examination of those early documents shows weak standards in terms of methodology and findings based on evidence (Hutz, Gauer, \& Gomes, 2012). Historically, the idea of postgraduate studies first reached Brazilian universities in the 1930s, with professors who left Europe because of political instability and the imminence of war. At that time, the university was organized in chairs. Underneath these chairs, the professors had the freedom to organize their research and define how the doctoral thesis would be submitted. The studies, therefore, took place informally, led by those professors who wished to offer them. Although these initiatives had not brought major impacts, they had served to highlight the importance of advanced studies and empirical research for personnel and 
institutional qualification.

Postgraduate studies were finally recognized by the federal government in 1965, when higher education was split into two levels: 1) baccalaureate for professional training, or licensure for basic and secondary teaching; and 2) master's and doctoral training for research and teaching. Three years later, in 1968, the government put in motion a profound educational reform at all levels, radically modifying the functioning of all higher education institutions. The reform adopted the US higher education system as a model. It created a career plan for faculty, and replaced the chair system with departments, with departmental faculty assuming teaching, research, and administrative roles within their respective fields of interest. Courses now were offered by the credit system, which replaced the existing mandatory serial system (Schwartzman, 1991; Sucupira, 1995).

It was the educational reform of 1968 led by Newton Sucupira (1920-2007) that began to shape postgraduate studies (Bomeny, 2014). Candidates for the master's and doctoral programs would have to complete a minimum number of specialized disciplines, pass qualifying exams, and defend a dissertation or thesis publicly in front of a committee of which one member was from another university.

There is a curious controversy surrounding the reversal of the name for the term paper for master's and doctoral degrees. In the US model, the word thesis described the final paper for the master's degree, while the word dissertation described the paper for the doctorate. According to educator and psychologist Joel Martins (1920-1993), in a lecture commemorating the twentieth anniversary of the Postgraduate Program in Psychology of Education at the Pontifícia Universidade Católica de São Paulo, the reversal resulted from a translation lapse (Martins, 1989). Thereafter, the Federal Council of Education that regulated postgraduate courses retained the terms as translated. However, we can interpret the word thesis as tied to the word doctorate, as used in many universities. This association is common, still today.

The requirements for accreditation of postgraduate programs, by the Federal Council of Education, were rigid and few universities were able to meet them at that time. Thus, growth was gradual, with universities having to wait for faculty qualification, to meet requirements for the new format. Yet, the introduction of postgraduate programs was important to the Brazilian government (Schwartzman, 1991). The country was in the hands of a nationalist military government interested in modernization and new technologies. Brazilian researchers, while not supporting the military government, shared the same scientific interests. Together, these convergent views supported changes, both in educational and scientific policy. Thus, the government launched an ambitious plan: the distribution of scholarships for faculty qualification. Previously, grants for research and scholarships were limited, and many came from foreign sources, such as the Ford Foundation or the Rockefeller Foundation. Funded by the new scholarships, teachers were now able to study in Europe and the US. Upon returning to Brazil, these teachers brought new knowledge to their field, and a more sophisticated understanding of the research standards held by scientists in the international community.

The development of postgraduate programs in this new format was slow. In psychology, the first master's degree was offered by the Pontificia Universidade Católica do Rio de Janeiro in 1966. Interestingly, PUC Rio was also the first university to offer a training program for psychologists

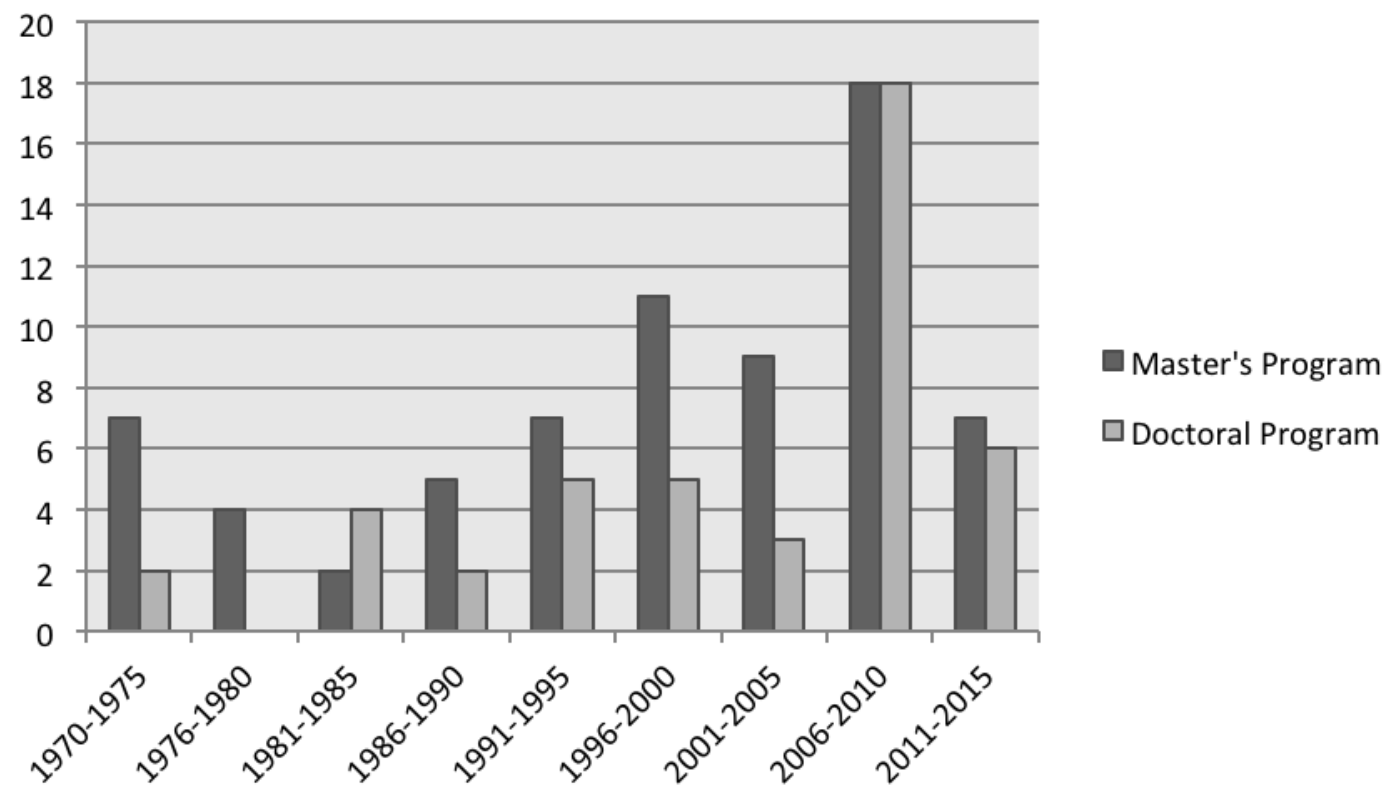

Figure 1. Growth trend of Master's and Doctoral programs in Brazil: 1970-2015. 
(undergraduate level) and maintained its leading status by being the first now to offer a master's in psychology. The first doctoral programs were offered by the Universidade de São Paulo in Experimental Psychology, and School and Human Development, in 1970. As indicated in Table 1 , the growth of both master's and doctoral programs was slow. The more established universities and qualified faculty launched their programs first of all; while younger institutions had to wait for the arrival of qualified faculty to organize their programs. This growth disparity was balanced out as the more established programs provided faculty for the younger, up-and-coming programs.

In the mid-1970s, administrative arrangements were needed to effectively consolidate postgraduate education. Thus, the Federal Council of Education (Conselho Federal de Educação - CFE) was instructed to certify both undergraduate and postgraduate programs. However, the Council was not prepared to assume this obligation. These new charges would require merit criterion development for the granting of research funds: a task CFE was not prepared, and did not have the structure, to undertake. At that time, CNPq already had a system of peer review for awarding research scholarships and grants. Nonetheless, $\mathrm{CNPq}$ did not accept the mission on the grounds that its system was designed to evaluate individual researchers and not programs. Thus, in 1975 CAPES assumed the task and launched a national plan for postgraduate studies that became known by the acronym CNPG. CNPG aimed to: 1) consolidate the postgraduate level within universities and assure stable funding; 2 ) raise the current standards of performance and rationalize the use of resources; and 3) increase its expansion, providing a more balanced structure between areas and regions. The results were seen in terms of awarding scholarships for full-time students, expanding institutional programs for faculty training, and hiring fulltime faculty on a regular basis for postgraduate education.

In the following year, CAPES conducted the first postgraduate program evaluation. Since then, evaluations were conducted every two years until 1997 when it became triennial. In 2014 it became quadrennial, given the substantial increase in the number of programs. Meanwhile, the PNPG was revised periodically to ensure: 1) consolidation and improvement of performance; 2) institutionalization of research inside universities; 3) integration of science and technology, promoting innovation; 4) integration with the private sector; 5) diversification of program models; 6) expansion of programs throughout all regions of the country (to reduce the concentration in the south and southeast regions); and 7) increasing international exchange.

Indeed, the plans and strategies of CAPES have played a key role in the implementation and consolidation of postgraduate studies in Brazil. This successful venture is due to the clarity of its guidance and assessment accuracy. Currently, programs are closely monitored by the online platform, Plataforma Sucupira, named in honor of prof.
Newton Sucupira. Sucupira, interestingly enough, was a lawyer and a follower of Germanic philosophy who spent the second half of 1959 in the US, visiting colleges and universities while on a mission for Anísio Teixeira. From this visit rose the basis for the educational reforms introduced in the 1960s, which brought profound changes to the administrative and pedagogical organization of Brazil's higher education system. ${ }^{5}$

The debates of the ANPEPP meetings in 2014 were consumed by our next step; that is, how to raise Brazil's status from that of a "developing nation" to a "developed nation," in terms of science and technology. As a developing nation, Brazil occupies the fifteenth position worldwide in scientific publications, and the first place among Latin American countries. But the transition from developing to developed nation will require substantial upgrades in both the quality and quantity of peer-reviewed publications, according to Scimago Country Rank. ${ }^{6}$

The challenge posed to researchers in psychology is how to disseminate their work and how to cooperate fruitfully with researchers abroad. Researchers working in related areas of the natural sciences are already well advanced in this process. In contrast, researchers in the humanities, although they cooperate with researchers from other countries, are more closely allied to the Brazilian journals and the Portuguese language. Yet, we have the commitment of postgraduate studies to produce material for the field of psychology in Brazil, with over 250,000 psychologists. Our hope is that CAPES and CNPq can support their research funding lines, including scholarships, internships abroad and post-doctoral activities; that state foundations for fostering research will be strengthened; and that the economic swings of policy do not derail the research at our public and private universities.

\section{Final remarks}

The study of psychology has a long tradition in Brazil, with the discipline arriving in the second half of the nineteenth century, following the ideas born in Europe at that time. Psychological scientific achievements grew slowly through the twentieth century in Brazil, and accelerated at the onset of the twenty-first century. In contrast, the psychology profession had grown rapidly in the second half of the twentieth century and was thus established as a well-recognized profession. Recent changes in educational order confirmed that the undergraduate degree in psychology (i.e., Brazilian graduate level) should be titled as a bachelor's degree and not psychologist, as it was in the beginning. We still have to strengthen the notion that psychological science must be empirically supported, but we are not alone in this endeavor. In fact, this is a problem in our discipline

\footnotetext{
Retrieved from: https:/www.capes.gov.br/images/stories/download/ diversos/2832014-Discurso-Plataforma-Sucupira-final.pdf

Retrieved from: http://www.scimagojr.com/countryrank.php; data from 1996 to 2013
} 
worldwide (Stanovich, 2004). In Brazil, CAPES' policies have provided strong support for our scientific progress. Postgraduate programs have responded positively to CAPES' policies, with encouraging results in the reports (Bastos et al., 2015). We are certain that in keeping with the current policies, even with the oscillations in the national economy, postgraduate education will grow steadily in its advance of the psychological sciences; and will be working towards a better quality of life, social justice and ecological sustainability. And on this journey, ANPEPP will continue as a privileged space for research articulation and science advancement, through its symposia and seminars.

\section{References}

Bastos, A. V. B., Tomanari, G. Y., Trindade, Z. A., \& Andery, M. A. P. A. (2015). The psychology postgraduate system in Brazil: Current characteristics and challenges for the area. Psicologia: Reflexão e Crítica, 28(suppl. 1), 23-33.

Bomeny, H. (2014). Um personagem e suas histórias. [A character and its histories] Cienc. Cult. [online], 66(4), 38-43. Retrieved from http://cienciaecultura.bvs.br/scielo.php?script $=$ sci arttext\&pid=S0009-67252014000400013\&lng=en\&nrm=iso

Camino, L., \& Schliemman, A. D. (1988). Avaliação geral dos trabalhos apresentados no I Simpósio Brasileiro de Pesquisa e Intercâmbio Científico da Anpepp: Como vai a pesquisa em Psicologia no Brasil? [General evaluation of the papers presented at the first ANPEPP Simposium]. In A. D. Schliemman \& J. T. R. Falcão (Eds), 1o. Simpósio Brasileiro de Pesquisa e Intercâmbio Científico da Anpepp (Anais, pp. 275-278). Rio de Janeiro: ANPEPP.

Campos, R H. F. (2001). Dicionário biográfico da psicologia no Brasil [Biographical dictionary of psychology in Brazil]. Rio de Janeiro/Brasília: Imago/CFP.

Centofanti, R. (1982). Radecki e a psicologia no Brasil [Radecki and psychoology in Brazil]. Psicologia: Ciência e Profissão, 3(1), 3-50.

Centofanti, R., \& Tomasini, M. B. (2014). O livro dos cem anos do Laboratório de Psicologia Experimental da Escola Normal Secundária de São Paulo [One hundred years of the first Laboratory of Experimental Psychology at Normal School, in Sao Paulo]. São Paulo: CDU.

Costa, J. C. (1967). Contribuição à história das ideias no Brasil [Contribution to the history of ideias in Brazil]. (2. ed).] Rio de Janeiro: Civilização Brasileira.

Cunha, L. A. C. R. (2007). Universidade temporã: O ensino superior da colonia à era Vargas [Premature university: Higher education from colonial times to Vargas]. 2. ed. São Paulo: Unesp.

Favero, M. L. A. (2010). Universidade do Brasil: Das origens à construção [ History of the University of Brazil]. Rio de Janeiro: Editora UFRJ.

Fradkin, C. (2015). A summary evaluation of the top-five Brazilian psychology journals by native English-language scholars. Psicologia: Reflexão e Crítica, 28(suppl. 1), 99-111.

França, E. F. (1972). Investigações psicológicas [Psychological investigations]. São Paulo: Grijalbo/USP. (Original work published 1854).

Gamba, E. C., Packer, A. L., \& Meneghini, R. (2015). Pathways to internationalize Brazilian journals of psychology. Psicologia: Reflexão e Crítica, 28(suppl. 1), 66-71.
Gracia, E. (2015). Psychosocial intervention: A journal's journey towards greater scientific quality, visibility and internationalization. Psicologia: Reflexão e Crítica, 28 (suppl. 1), 94-98.

Gomes, W. B. (2003). Pesquisa e prática em psicologia no Brasil [Psychology research and practice in Brazil]. In O. H. Yamamoto \& V. V. Gouveia (Eds), Construindo a psicologia brasileira: Desafios da ciência e da prática psicológica [Shaping Brazilian psychology: Challenges of science and psychological practice]. São Paulo: Casa do Psicólogo.

Guedes, M. C. (2002). Para uma história da ANPEPP: Entrevista com Marcos Formiga [For a history of ANEPP: Interview with Marcos Formiga]. Retrieved from http://www.anpepp.org.br/ old/1-Acervo/B-historico/hist_anpepp.htm

Guzzo, R. S. L., Linhares, M. B. M., Teodoro, M. L. M., \& Koller, S. H. (2015). Prospects and challenges of Brazilian policies for research and postgraduate studies in psychology. Psicologia: Reflexão e Crítica, 28(suppl. 1), 34-39.

Hearnshaw, L. S. (1987). The shaping of modern psychology. London/New York: Routledge \& Kegan Paul.

Hutz, C., Gauer, G., \& Gomes, W. B. (2012). Brazil. In David B. Baker (Ed.). The Oxford handbook of the History of Psychology: Global perspectives (pp. 34-50). Oxford: Oxford University Press.

Leitão, S., Falcão, T. R., \& Maluf, M. R. (2015). Ethical standards of scientific research involving human subjects in Brazil: Perspectives concerning Psychology. Psicologia: Reflexão e Crítica, 28(suppl. 1), 40-48.

Lo Bianco, A. C., Hutz, C. S., \& Yamamoto, M. Y. (2015). Internationalization: Towards new horizons. Psicologia: Reflexão e Crítica, 28(suppl. 1), 49-56..

Lopez-Lopez, W., Anegón, F. M., Acevedo-Triana, C., \& Garcia, A. (2015). Psychological research collaboration and visibility in Iberoamerica. Psicologia: Reflexão e Crítica, 28(suppl. 1), $72-81$

Lucchesi, M. A. S. (2011). O ensino superior brasileiro e a influência do modelo francês [Brazilian higher education and the French model influence]. In IV Colóquio Internacional sobre Gestão Universitária na América do Sul. Retrieved from https://repositorio.ufsc.br/bitstream/handle/123456789/2953 4/7.2.pdf? sequence $=1$

Martins, J. (1989). Vinte anos de Pós-Graduação da Psicologia da Educação - 1969-1989. [Twenty years of Postgraduate Program in Educational Psychology at PUCSP - 1969-1989] Retrieved from http://www.pucsp.br/pos-graduacao/mestradoe-doutorado/educacao-psicologia-da-educacao\#historia

Massimi, M. (1990). História da psicologia brasileira: Da época colonial até 1934 [History of Brazilian psychology: From colonial times until 1934]. São Paulo: EPU.

Menandro, P. R. M., Linhares, M. B. M., Bastos, A., \& Dell'Aglio D. D. (2015). The Brazilian psychology postgraduate system and the internationalization process: critical aspects, evaluation indicators and challenges for consolidation. Psicologia: Reflexão e Crítica, 28(suppl. 1), 57-65.

Mendonça, A. W. P. C. (2004). A pós-graduação como estratégia de reconstrução da Universidade Brasileira. Educar em Revista, 21. [The postgraduate education as reconstruction strategy for the Brazilian University] Retrieved from http:// ojs.c3sl.ufpr.br/ojs2/index.php/educar/article/view/2136/1788

Meneghini, R., \& Packer, A. L. (2007). Is there science beyond English? EMBO reports, 8, 112-116.

Oliven, A. C. (2014). Higher education in the United States and Brazil: How the two systems origins shaped their further 
Gomes, W. B. \& Fradkin, C. (2015). Historical Notes on Psychology in Brazil: The Creation, Growth and Sustenance of Postgraduate Education.

development. Creative Education, 5, 1662-1672. Retrieved from http://dx.doi.org/10.4236/ce.2014.518184

Pessotti, I. (1988). Notas para uma história da psicologia brasileira [Notes for a history of psychology in Brazil]. In Conselho Federal de Psicologia (Ed.), Quem é o psicólogo brasileiro? [Who is the Brazilian psychologist?] (pp. 17-31). São Paulo: Edicon.

Schliemann, A. D. (2015). ANPEPP: Symposia, research, and postgraduate studies from 1988 to 2014. Psicologia: Reflexão e Crítica, 28(suppl. 1), 14-18.

Schliemman, A. D., \& Falcão, J. T. R (1988). Apresentação [Presentation]. In A. D. Schliemman \& J. T. R. Falcão (Eds.), 1o. Simpósio Brasileiro de Pesquisa e Intercâmbio Científico da Anpepp (Anais, pp. 11-12). Rio de Janeiro: ANPEPP.

Schwartzman, S. A. (1991). A space for science: The development of the scientific community in Brazil. University Park: Pennsylvania State University Press. Retrieved from http:// www.schwartzman.org.br/simon/space/ summary.htm

Stanovich, K. (2004). How to think straight about psychology. Boston: Pearson.

Sucupira, N. (1965). Definição dos cursos de pós-graduação [Definition of the postgraduate courses]. Revista Brasileira de Estudos Pedagógicos, 44(100), 67-86. (Parecer CFE 977/1965).

Teixeira, A. (1989). Ensino superior no Brasil: Análise e interpretação de sua evolução até 1969 [Higher education in Brazil: Analysis and interpretation of its evolution until 1969]. Rio de Janeiro: FGV.

Tourinho E. Z., \& Bastos, A. V. B. (2010). Challenges to graduate courses in psychology in Brazil. Psicologia: Reflexão e Crítica, 23(suppl. 1), 35-46.

USP: Estudos Avançados (1994). Fernando Novais Braudel e a "missão francesa" [Braudel and the "French mission"]. Estudos Avançados, 8(22), 161-166. Retrieved from http:// www.scielo.br/scielo.php?script=sci_arttext\&pid=S010340141994000300014\&lng=en\&tlng=pt. 10.1590/S010340141994000300014.

VandenBos, G. R., \& Winkler, J. M (2015). An analysis of the status of journals and research in psychology from Latin America. Psicologia: Reflexão e Crítica, 28(suppl. 1), 82-93. 